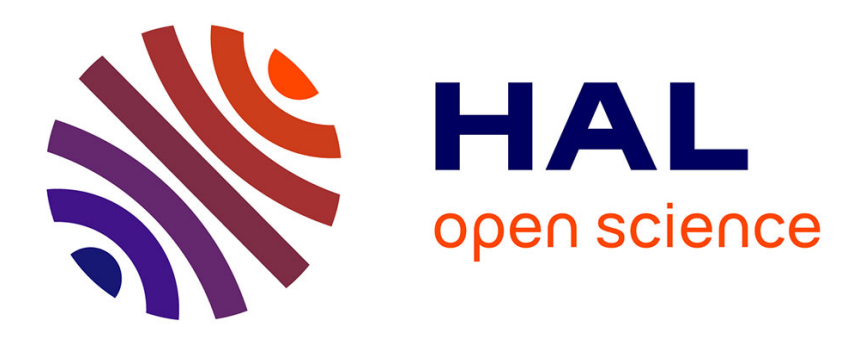

\title{
Adaptation and customization of services for the elderly
} André Thépaut, Maria-Teresa Segarra, Christophe Lohr, Pierre-Marie Chapon

\section{To cite this version:}

André Thépaut, Maria-Teresa Segarra, Christophe Lohr, Pierre-Marie Chapon. Adaptation and customization of services for the elderly. 7th world conference ISG10: International Society for Gerontechnology , May 2010, Vancouver, Canada. hal-01759102

\section{HAL Id: hal-01759102 \\ https://hal.science/hal-01759102}

Submitted on 4 Sep 2018

HAL is a multi-disciplinary open access archive for the deposit and dissemination of scientific research documents, whether they are published or not. The documents may come from teaching and research institutions in France or abroad, or from public or private research centers.
L'archive ouverte pluridisciplinaire $\mathbf{H A L}$, est destinée au dépôt et à la diffusion de documents scientifiques de niveau recherche, publiés ou non, émanant des établissements d'enseignement et de recherche français ou étrangers, des laboratoires publics ou privés. 


\title{
Adaptation and customization of services for the elderly
}

\author{
A. Thépaut, M.T. Segarra, C. Lohr, P.M. Chapon
}

Address: Institut TELECOM; Telecom Bretagne, Technopôle de Brest Iroise, 29238 Brest Cedex 3, France

Keywords: Multimedia services on TV set, services co-design for the aged, design for all.

Information and communication technologies may be used to improve the quality of life of elderly people. However, the use of such techniques may be challenging for the elderly. In this paper, we present our experience on the deployment and experimentation of ICT technologies for older people that lead us to focus our work on adaptation.

\section{Methods}

Since 2001, the SID research group of Telecom Bretagne works on proposing a service-oriented platform intended to help people with disabilities to improve their quality of life. The platform is composed of a set of servers and interaction devices to access available services. These devices have been advocated by the end users themselves and concern a TV set and its remote control device. The platform [1] was intended to be deployed and evaluated by seniors in a retirement home in the district of Bellevue in Brest by June 2009. The district of Bellevue was chosen due to strong relationships between the SID team and the City Hall, associations, and social services. In order to identify services to be developed, a team of sociologists interviewed the technical staff, elderly people, caregivers of the retirement home, and local authorities during six months. Four types of services have been identified: (i) communication with the social network of the elderly; (ii) infotainment services, and in particular accessing local news; (iii) management of daily activities; (iv) access to individual games or multi-players.

\section{Results and discussion}

Early returns showed the difficulties experienced by some seniors to access services. For example, seniors who suffer from muscular problems have great difficulties in using the first proposed remote control device which was not stable enough. The visually impaired people cannot read text on the television. So a text to speech system was added to the platform. Nevertheless, the adaptation of services for each person need seems impossible in the context of a deployment on a larger scale.

Therefore, we are currently working in a new project, SIGAAL, (Special Interest Group on Ambient Assisted Living), supported by French State ("Direction Générale des Entreprises"). The project brings together 11 partners and will focus on adaptation of services. It allows for low cost devices helping on maintaining or even strengthen social ties and detecting incipient vulnerabilities of older people at home. In this sense, work is underway on changing size and font of characters in real time to address each individual reader and to adapt to her current capabilities. We are also working on an expressive text to speech system that is able to vocalize text using the voice of the person with whom one exchange messages. Finally, as adapting services depends on elderly capabilities as well as the execution environment where services execute, developing each configuration is not a satisfying solution. Moreover, changing from one configuration to another may be challenging depending on the changes to be performed. Therefore, we intend to propose a methodology for automating the development of adaptation mechanisms based on the work proposed by [2] and [3].

\section{References}

1. Companymages Project Home Page. https://www.companymages.eu. Last visited jan 2010.

2. E. Kaboré, A. Beugnard: Implementing a Data Distribution Variant with a Metamodel, Some Models and a Transformation. In Procs. $8^{\text {th }}$ IFIP DAIS, Oslo, Norway, 2008.

3. A. Phung Khac, A. Beugnard, J.M. Gilliot, M.T. Segarra. Model-Driven Development of Component-based Adaptive Distributed Applications. In Procs $23^{\text {rd }}$ Annual ACM SAC, Fortaleza, Brésil, 2008. 